\title{
Protein profiling of post-prostatic massage urine specimens by surface-enhanced laser desorption/ionization time-of-flight mass spectrometry to discriminate between prostate cancer and benign lesions
}

\author{
AKIKO OKAMOTO $^{1}$, HAYATO YAMAMOTO ${ }^{1}$, ATSUSHI IMAI ${ }^{1}$, SHINGO HATAKEYAMA ${ }^{1}$, \\ IKUYA IWABUCHI $^{1}$, TAKAHIRO YONEYAMA ${ }^{1}$, YASUHIRO HASHIMOTO ${ }^{1}$, TAKUYA KOIE $^{1}$, \\ NORITAKA KAMIMURA ${ }^{1}$, KAZUYUKI MORI ${ }^{1}$, KANEMITSU YAMAYA ${ }^{2}$ and CHIKARA OHYAMA ${ }^{1}$ \\ ${ }^{1}$ Department of Urology, Hirosaki University Graduate School of Medicine, 5 Zaifu-cho, Hirosaki 036-8562; \\ ${ }^{2}$ Oyokyo Kidney Research Institute, 90 Kozawa Yamazaki, Hirosaki 036-8243, Japan
}

Received August 5, 2008; Accepted September 29, 2008

DOI: 10.3892/or_00000191

\begin{abstract}
Post-prostatic massage urine specimens (PMUS) are expected to be rich in proteins originating from the prostatic acini. In this study, we created a PMUS bank consisting of 57 samples obtained from patients with biopsy-proven prostate cancer (PC) and 56 samples from subjects with biopsy-proven benign lesions to analyze protein profiles of PMUS by surface-enhanced laser desorption/ionization time-of-flight mass spectrometry (SELDI-TOF MS). Strong anion-exchange (Q10), weak cation-exchange (CM10) and immobilized metal affinity capture (IMAC30) ProteinChip Arrays were used for protein profiling. In PC samples, single-marker analysis detected 49 mass peaks that were significantly up-regulated and 23 peaks that were significantly down-regulated, compared with peaks obtained from benign lesion samples. To confirm reproducibility we performed additional three rounds of assay using CM10 chip with pH 4.0 binding buffer. Among these significant peaks, a peak of $\mathrm{m} / \mathrm{z} 10788$ was significant throughout all 4 rounds of assays. For hierarchical clustering analysis (HCA), we used the 72 peaks which revealed significant differences in single-marker analysis. The heat map discriminated PC from benign lesions with a sensitivity of $91.7 \%$ and a specificity of $83.3 \%$. Therefore, SELDI-TOF MS profiling of PMUS can be applied to differentiate patients with PC from cancer-free subjects. However, further investigation is required to verify the usefulness of this method in clinical practice.
\end{abstract}

Correspondence to: Dr Chikara Ohyama, Department of Urology, Hirosaki University Graduate School of Medicine, 5 Zaifu-cho, Hirosaki 036-8562, Japan

E-mail: coyama@cc.hirosaki-u.ac.jp

Key words: protein profile, prostate cancer, prostate massage

\section{Introduction}

Prostate cancer (PC) is the most common type of cancer in men and the second highest cause of cancer death in the United States (1). Recently, mortality rates for PC have been increasing dramatically in Japan (2). Early detection of PC has become easier by measuring prostate-specific antigen (PSA); however, an urgent need exists for novel biomarkers to improve the specificity of PC detection.

A number of innovations have been made to improve the specificity of PSA testing. The most successful of these, measurement of alternative molecular forms of PSA expressed as the percentage of free PSA, improves the diagnostic specificity of PSA testing $(3,4)$ and can decrease the number of false-negative prostate biopsies by $\sim 20-25 \%$ (5). Moreover, PSA velocity, age-specific PSA, PSA density and proPSA have been postulated to improve the specificity of PSA testing (6). However, the incidence of PC is shown as high as $22 \%$ among men with a normal PSA range, 2.6-4.0 $\mathrm{ng} / \mathrm{ml}$ (7). Furthermore, PSA testing is almost organ-specific, but not cancer-specific, because elevated serum concentrations are also found in benign diseases, such as benign prostatic hypertrophy and prostatitis. Therefore, great emphasis has been placed on the need to discover novel biomarkers for use in PC diagnosis.

Proteomic techniques applied to serum or plasma may provide valuable information regarding protein markers or patterns of markers that could possibly be used to improve cancer detection (8). Serum protein profiling with surface enhanced laser desorption/ionization time-of-flight mass spectrometry (SELDI-TOF MS) has been shown to detect cancers, including PC (9). In addition, several case-control studies have reported excellent validity for PC detection (10-13).

Serum proteomic approaches have not provided useful biomarkers for PC in a clinical setting. In order to address this problem, we conducted a proteomic study on protein originating from prostate acini obtained by non-invasive sampling. Post-prostatic massage urine specimens (PMUS), 
which have been established as diagnostic samples for prostatitis (14), are expected to be rich in proteins originating from prostatic acini. Moreover, to our knowledge, this is the first detailed study describing protein profiling of PMUS by SELDI-TOF MS.

\section{Materials and methods}

Post-prostatic massage urine specimen (PMUS). A flowchart of this study is illustrated in Fig. 1. PMUS was collected after digital rectal examination (5 strokes per lobe). Urine was voided into urine collection cups, briefly centrifuged (10 min at 2,000 x g), aliquotted, frozen immediately and stored at $-80^{\circ} \mathrm{C}$ until protein profile analysis. The PMUS bank consisted of 57 samples from patients with biopsyproven PC and 56 samples from subjects with biopsy-proven benign lesions. The study was approved by the Institutional Ethics Committee and a written consent was obtained from all subjects who participated in the study.

Protein concentration measurement and prostate-specific antigen assay. Protein concentration of PMUS was measured by Immage 800 (Beckman Coulter Inc., Brea, CA, USA) and prostate-specific antigen (PSA) in serum was measured by Immulite 1000 (Siemens, Deerfield, IL, USA).

Prostate biopsy and pathological diagnosis. After collection of PMUS, 10 or 12 prostate needle biopsy samples were transrectally obtained by ultrasound guidance, using an $18 \mathrm{G}$ needle. The 2002 TNM staging system (15) was used to assign the stage and the up-dated Gleason grading system from the International Society of Urological Pathology (ISUP) (16) was used for tumor grading.

Analysis of protein profiles. PMUS samples were briefly centrifuged (10 min at $20,000 \mathrm{x} \mathrm{g})$ and the supernatants were subjected to protein profiling. Protein profiles of the PMUS samples were obtained by using weak cationexchange (CM10), strong anion-exchange (Q10) and immobilized metal affinity capture (IMAC30) ProteinChip Arrays (Bio-Rad, Fremont, CA, USA). The ProteinChip Arrays were assembled into a deep-well type Bioprocessor assembly (Bio-Rad). Prior to sample loading, Q10 and CM10 arrays were equilibrated with $150 \mu \mathrm{l}$ of binding buffer (for Q10, $50 \mathrm{mM}$ Tris-HCl, pH 8.0; for CM10, $100 \mathrm{mM}$ sodium acetate, pH 4.0 and 50 mM HEPES, pH 7.0). Before the samples were loaded, IMAC30 arrays were charged with $\mathrm{Cu}^{2+}$ by adding $50 \mu 1$ of $100 \mathrm{mM} \mathrm{CuSO}_{4}$. After incubation for $5 \mathrm{~min}$, the arrays were quickly rinsed with water to remove the unbound metal and the surface was further washed with $50 \mu 1$ of $100 \mathrm{mM}$ sodium acetate, $\mathrm{pH}$ 4.0. The arrays were then equilibrated with $150 \mu \mathrm{l}$ of binding buffer (100 $\mathrm{mM}$ sodium phosphate with $0.5 \mathrm{M} \mathrm{NaCl}$, $\mathrm{pH} 7.0)$.

A $10 \mu 1$-portion of PMUS was mixed with $30 \mu 1$ of $2 \%$ CHAPS/9 M urea/50 mM Tris-HCl, $\mathrm{pH} 9.0$ and further diluted with $60 \mu 1$ of binding/washing buffer. All arrays were then incubated with $100 \mu \mathrm{l}$ of diluted sample for $60 \mathrm{~min}$ on a shaker and washed 3 times with $150 \mu$ l of binding buffer. After rinsing with water, the arrays were removed from the Bioprocessor

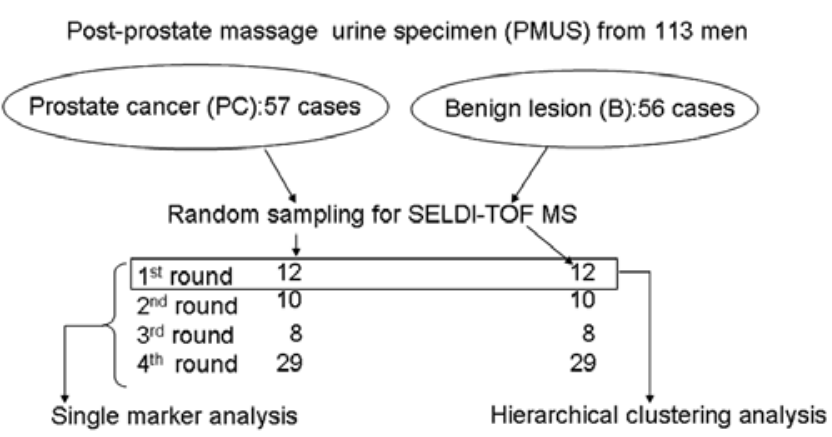

Figure 1. The study design. The PMUS sample bank consisted of 57 samples from patients with biopsy-proven PC and 56 samples from subjects with biopsy-proven benign lesions. PMUS samples were randomly selected for protein profiling. Overall, 39 samples from benign lesions and 37 samples from PC were subjected to single-marker analysis. Twelve samples from each pool were subjected to hierarchical clustering analysis (HCA).

assembly and air-dried. After air-drying, a $1.0 \mu \mathrm{l}$ aliquot of $50 \%$ saturated sinapinic acid solution (dissolved in $50 \%$ acetonitrile containing $0.5 \%$ trifluoroacetic acid) was added twice and allowed to dry.

The ProteinChip Arrays were then transferred to the ProteinChip System Series 4000 (Bio-Rad) which generates nanosecond laser pulses from a UV-emitting pulsed nitrogen laser (373 nm). External mass calibration was performed with protein standards: porcine dynorphin (2148 Da), human adrenocorticotropic hormone (2934 Da), bovine insulin B-chain (3496 Da), human insulin (5808 Da), recombinant hirudin (6964 Da), bovine cytochrome C (12230 Da), equine myoglobin (16951 Da), bovine carbonic anhydrase (29023 Da) and enolase from Saccharomyces cerevisiae (46671 Da). All assays were repeated twice.

The protein expression patterns were analyzed using CiphergenExpress Data Manager software, version 3.0 (Bio-Rad), which generates consistent mass peak sets (clusters) across multiple spectra and enables automatic comparison. Each cluster was treated as a single protein or peptide fragment. All data were normalized by the software's total ion current normalization function, following the manufacturer's instructions. Spectra between 2500 and 150000 mass-to-charge ratios $(\mathrm{m} / \mathrm{z})$ were selected for analysis. Automatic peak detection was carried out for peaks with signal/noise ratio $>2.5$. The Mann-Whitney $U$ test was used to compare intensities of clustered peaks between the 2 sample groups.

Single-marker analysis. To identify a candidate peak, we used CM10, Q10 and IMAC 30 chips. To confirm reproducibility, we carried out additional 3 rounds of analysis by CM10 chip with $\mathrm{pH} 4.0$ binding buffer. PMUS were randomly selected from each group for each round. For the first round analysis, we randomly selected 12 samples each from the PC-PMUS pool and the benign lesion-PMUS pool. For the second, third and fourth round analyses, we randomly selected 10, 8 and 29 samples from each group, respectively (Fig. 1). Finally, 37 PC samples and 39 benign lesion samples were examined for single-marker analysis. Demographic data on the subjects are shown in Table I. 
Table I. Demographic data on subjects for single-marker analysis.

\begin{tabular}{lcr}
\hline & $\mathrm{B}(\mathrm{n}=39)$ & $\mathrm{PC}(\mathrm{n}=37)$ \\
\hline Age (years) (mean; range) & $68.0(53-81)$ & $70.3(53-79)$ \\
Serum PSA (ng/ml) (mean; range) & $6.9(2.1-12.5)$ & $15.7(4.4-111.2)$ \\
PMUS protein conc. $(\mu \mathrm{g} / \mathrm{ml})$ (mean; range) & $102.3(27.2-353.5)$ & $113.5(25.1-338.1)$ \\
Gleason score (mean; range) & - & $7.3(5-9)$ \\
Clinical stage & - & $\mathrm{T} 1 \mathrm{cN} 0 \mathrm{M} 0-\mathrm{T} 4 \mathrm{~N} 1 \mathrm{M} 1$ \\
\hline
\end{tabular}

PMUS, post-prostate massage urine specimen; B, benign lesion and PC, prostate cancer.

Table II. Clinicopathological data on subjects used for hierarchical clustering analysis (HCA).

\begin{tabular}{|c|c|c|c|c|c|c|}
\hline Case & $\begin{array}{l}\text { Age } \\
\text { (year) }\end{array}$ & $\begin{array}{l}\text { Serum PSA } \\
(\mathrm{ng} / \mathrm{ml})\end{array}$ & Pathology & $\begin{array}{l}\text { Gleason } \\
\text { score }\end{array}$ & $\begin{array}{l}\text { Clinical } \\
\text { stage }\end{array}$ & $\begin{array}{c}\text { PMUS } \\
\text { concentration }(\mu \mathrm{g} / \mathrm{ml})\end{array}$ \\
\hline B1 & 74 & 6.8 & B & - & - & 140.4 \\
\hline B2 & 70 & 7.2 & B & - & - & 27.2 \\
\hline B3 & 72 & 7.3 & B & - & - & 123.6 \\
\hline B4 & 75 & 8.8 & B & - & - & 41.3 \\
\hline B5 & 61 & 2.5 & B & - & - & 278.1 \\
\hline B6 & 68 & 6.6 & B & - & - & 57.1 \\
\hline B7 & 57 & 6.6 & B & - & - & 76.0 \\
\hline B8 & 60 & 12.3 & B & - & - & 57.1 \\
\hline B9 & 66 & 4.1 & B & - & - & 38.1 \\
\hline B10 & 71 & 4.9 & B & - & - & 53.9 \\
\hline B11 & 70 & 8.3 & B & - & - & 34.9 \\
\hline B12 & 68 & 5.2 & B & - & - & 70.7 \\
\hline PC1 & 74 & 5.2 & $\mathrm{PC}$ & 7 & T2aNOM0 & 45.7 \\
\hline PC2 & 76 & 12.2 & $\mathrm{PC}$ & 7 & T1cN0M0 & 291.9 \\
\hline PC3 & 74 & 11 & $\mathrm{PC}$ & 7 & T2aNOM0 & 271.3 \\
\hline PC4 & 67 & 15.2 & $\mathrm{PC}$ & 7 & T3N0M1 & 25.1 \\
\hline PC5 & 72 & 5.8 & $\mathrm{PC}$ & 9 & T3N0M0 & 46.5 \\
\hline PC6 & 71 & 76.8 & $\mathrm{PC}$ & 9 & T3N0M0 & 40.7 \\
\hline PC7 & 76 & 9.2 & $\mathrm{PC}$ & 7 & T2aNOM0 & 144.8 \\
\hline PC8 & 68 & 7.8 & $\mathrm{PC}$ & 9 & T2aNOM0 & 102.3 \\
\hline PC9 & 75 & 15.5 & $\mathrm{PC}$ & 7 & T2aNOM0 & 44.4 \\
\hline PC10 & 77 & 34.5 & $\mathrm{PC}$ & 7 & T3N0M0 & 86.5 \\
\hline PC11 & 63 & 8.6 & $\mathrm{PC}$ & 7 & T2aNOM0 & 86.5 \\
\hline PC12 & 75 & 8.8 & $\mathrm{PC}$ & 7 & T2bNOM0 & 138.1 \\
\hline
\end{tabular}

PMUS, post-prostate massage urine specimen; B, benign lesion and $\mathrm{PC}$, prostate cancer.

Hierarchical clustering analysis (HCA). HCA was performed to create a heat map using CiphergenExpress Data Manager software, version 3.0 (Bio-Rad). For HCA analysis, we used the 72 peaks, which revealed significant differences in single-marker analysis. Clinicopathological data on the subjects whose PMUS were subjected to HCA are shown in Table II.

\section{Results}

In normal urine samples from healthy subjects, protein cannot be detected. However, protein concentration of PMUS was successfully measurable in all specimens as shown in Table I. Mean protein concentration of PMUS from patients with PC was $102.3 \mu \mathrm{g} / \mathrm{ml}$ and that from benign lesion was $113.5 \mu \mathrm{g} / \mathrm{ml}$. 

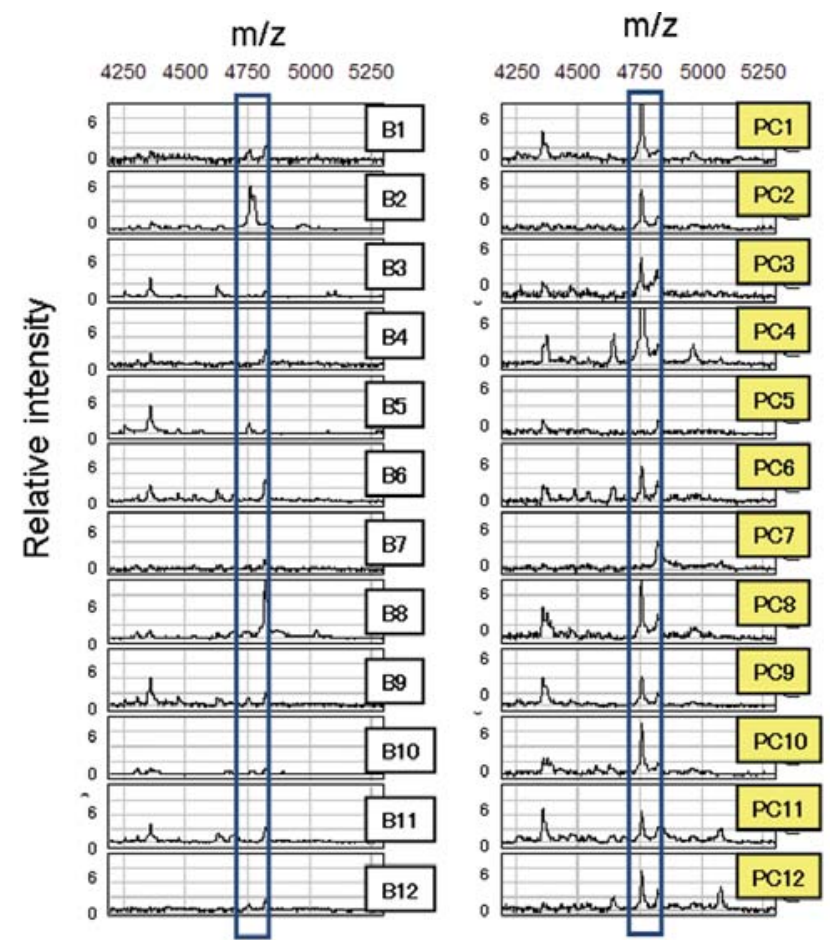

Figure 2. Protein profiling using CM10 chip with $\mathrm{pH} 4.0$ buffer. The peak intensity of $\mathrm{m} / \mathrm{z} 4761$, surrounded by line, was markedly higher in the PC group than in the benign lesion group.
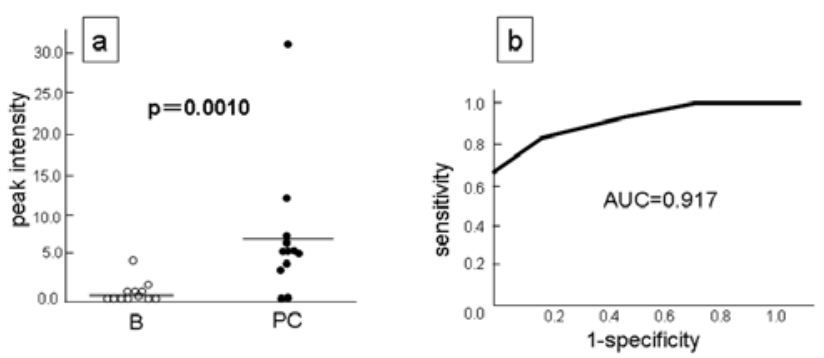

Figure 3. Difference in peak intensity of $\mathrm{m} / \mathrm{z} 4761$ between PC and benign lesion groups. (a) The peak intensity of $\mathrm{m} / \mathrm{z} 4761$ was significantly higher in the PC group $(\mathrm{P}=0.0010)$. (b) The receiver operating characteristic curve (ROC) was plotted for $\mathrm{m} / \mathrm{z} 4761$. The area under the curve (AUC) on the ROC plot was 0.917 .

PMUS protein concentration ranged from $25.1 \mu \mathrm{g} / \mathrm{ml}$ to $353.5 \mu \mathrm{g} / \mathrm{ml}$. Therefore, we diluted PMUS sample with $2 \%$ CHAPS/9 M urea/50 mM Tris- $\mathrm{HCl}$ to obtain final protein concentration of $25.0 \mu \mathrm{g} / \mathrm{ml}$.

For single-marker analysis, peak intensities detected by three kinds of chips were compared between the 2 groups. As a demonstrable example, protein profiles of the first assay round are presented in Fig. 2. The peak intensity of $\mathrm{m} / \mathrm{z}$ 4761 in the PC group was significantly higher than peaks in the benign lesion group ( $\mathrm{P}=0.0010$; Fig. 3a). The receiver
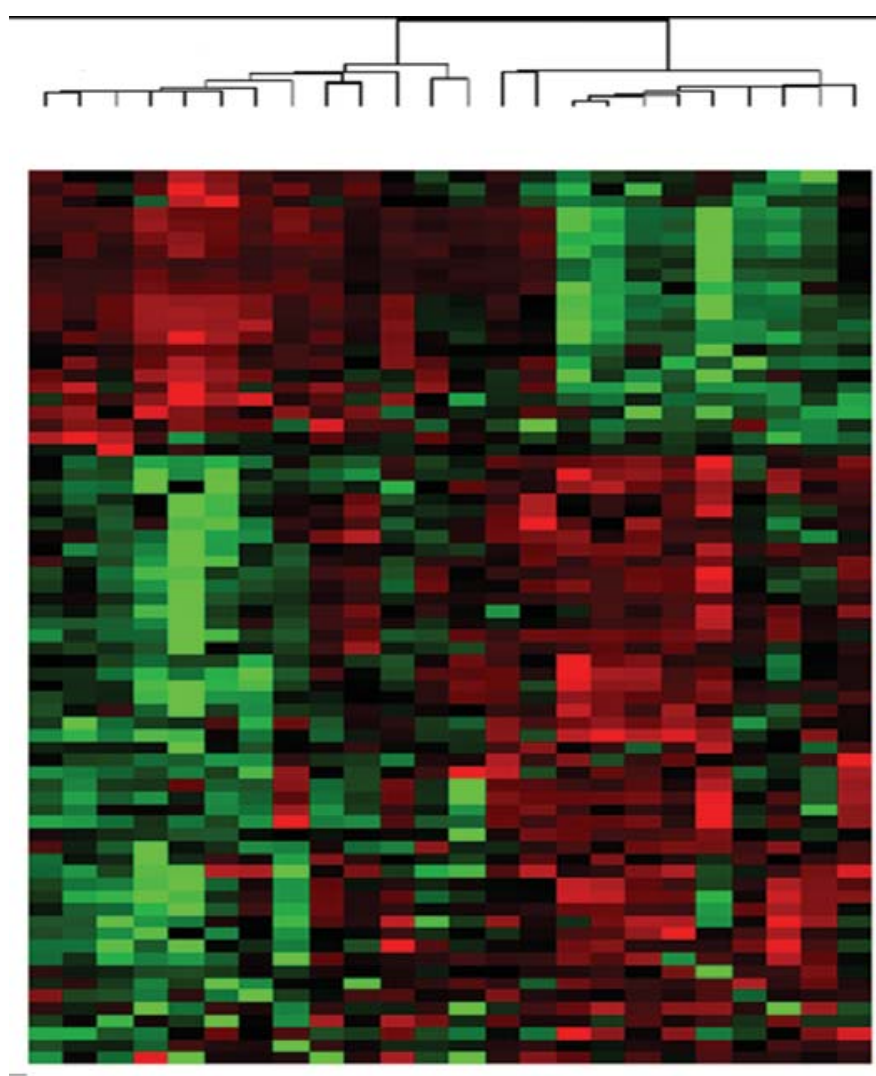

MIZ Chip condition

\begin{tabular}{|c|c|c|}
\hline 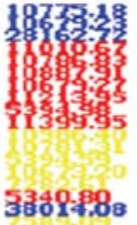 & 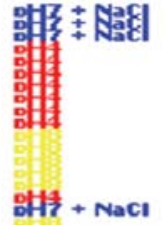 & $\begin{array}{l}\text { Chip condition (vertical) } \\
\square \mathrm{pH} 4 \\
\square \mathrm{pH} 7+\mathrm{NaCl} \\
\square \mathrm{pH} 7+\mathrm{HEPES} \\
\square \mathrm{pH} 8\end{array}$ \\
\hline $\begin{array}{l}902.69 \\
33-96 \\
36\end{array}$ & 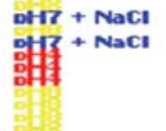 & $\begin{array}{l}\text { Grouping (horizontal) } \\
\square \text { B: benign lesion } \\
\square \text { PC: prostate cancer }\end{array}$ \\
\hline $\begin{array}{l}78: 53 \\
58: 65 \\
18: 935\end{array}$ & 鄂 & $\begin{array}{l}\text { Heat map (center) } \\
\square \text { up-regulate } \\
\square \text { down-regulate }\end{array}$ \\
\hline
\end{tabular}

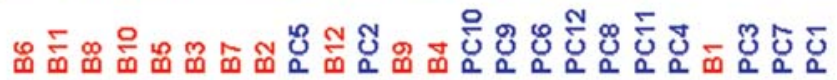

Figure 4. Heat map based on the results of protein profiling, using hierarchical clustering analysis. Horizontal line below the heat map represents case number. Vertical line represents the 72 significant peaks and chip conditions, which correspond to peak information presented in Table IV. According to the heat map, we were able to discriminate PC from benign lesions with $91.7 \%$ sensitivity and $83.3 \%$ specificity. B, benign lesion and PC, prostate cancer. 
Table III. Statistical data and chip conditions of significant peaks detected in single-marker analysis.

\begin{tabular}{|c|c|c|c|c|c|c|c|}
\hline \multicolumn{4}{|c|}{ peaks detected in single-marker analysi } & & & & \\
\hline \multirow{2}{*}{$\mathrm{M} / \mathrm{Z}$} & \multirow{2}{*}{ P-value } & \multirow{2}{*}{$\mathrm{ROC}$ area } & \multirow{3}{*}{ Chip condition } & $\mathrm{M} / \mathrm{Z}$ & P-value & $\mathrm{ROC}$ area & Chip condition \\
\hline & & & & \multirow{2}{*}{\multicolumn{4}{|c|}{ Up-regulated in PC }} \\
\hline \multirow{2}{*}{\multicolumn{4}{|c|}{ Up-regulated in $\mathrm{PC}$}} & & & & \\
\hline & & & & 9905 & 0.0056 & 0.806 & CM10 pH 4.0 \\
\hline 2670 & 0.0027 & 0.861 & CM10 pH 4.0 & 9990 & 0.0209 & 0.750 & CM10 pH 4.0 \\
\hline 2776 & 0.0282 & 0.750 & CM10 pH 4.0 & & & & \\
\hline 2797 & 0.0243 & 0.722 & CM10 pH 4.0 & \multicolumn{4}{|c|}{ Down-regulated in PC } \\
\hline 2978 & 0.0056 & 0.806 & CM10 pH 4.0 & 4702 & 0.0496 & 0.778 & Q10 pH 8.0 \\
\hline 3003 & 0.0010 & 0.861 & CM10 pH 4.0 & 4827 & 0.0496 & 0.722 & IMAC30 \\
\hline 3023 & 0.0005 & 0.889 & CM10 pH 4.0 & 5333 & 0.0496 & 0.722 & CM10 pH 4.0 \\
\hline 3174 & 0.0282 & 0.778 & Q10 pH 8.0 & 5339 & 0.0433 & 0.750 & Q10 pH 8.0 \\
\hline 3204 & 0.0496 & 0.722 & IMAC30 & 5384 & 00039 & 0.833 & CM10 pH 4.0 \\
\hline 3272 & 0.0111 & 0.778 & IMAC30 & 5395 & 0.0067 & 0.806 & Q10 pH 8.0 \\
\hline 3375 & 0.0079 & 0.806 & Q10 pH 8.0 & 7281 & 0.0153 & 0.778 & Q10 pH 8.0 \\
\hline 3461 & 0.0012 & 0.889 & CM10 pH 4.0 & 7589 & 0.0094 & 0.778 & Q10 pH 8.0 \\
\hline 3496 & 0.0022 & 0.889 & CM10 pH 4.0 & 7764 & 0.0027 & 0.861 & Q10 pH 8.0 \\
\hline 3721 & 0.0018 & 0.861 & CM10 pH 4.0 & 10668 & 0.0111 & 0.806 & Q10 pH 8.0 \\
\hline 3773 & 0.0027 & 0.833 & CM10 pH 4.0 & 10677 & 0.0153 & 0.778 & IMAC30 \\
\hline 3786 & 0.0496 & 0.722 & Q10 pH 8.0 & 10678 & 0.0153 & 0.806 & CM10 pH 4.0 \\
\hline 3851 & 0.0022 & 0.861 & CM10 pH 4.0 & 10778 & 0.0094 & 0.778 & IMAC30 \\
\hline 3897 & 0.0377 & 0.750 & CM10 pH 4.0 & 10782 & 0.0079 & 0.806 & Q10 pH 8.0 \\
\hline 3938 & 0.0209 & 0.750 & CM10 pH 4.0 & 10788 & 0.0067 & 0.806 & CM10 pH 4.0 \\
\hline 3997 & 0.0243 & 0.778 & Q10 pH 8.0 & 10888 & 0.0179 & 0.806 & CM10 pH 4.0 \\
\hline 4026 & 0.0079 & 0.806 & CM10 pH 7.0 & 10985 & 0.0067 & 0.833 & Q10 pH 8.0 \\
\hline 4028 & 0.0002 & 0.917 & CM10 pH 4.0 & 10995 & 0.0111 & 0.806 & CM10 pH 4.0 \\
\hline 4056 & 0.0243 & 0.778 & Q10 pH 8.0 & 11201 & 0.0153 & 0.778 & CM10 pH 4.0 \\
\hline 4478 & 0.0377 & 0.750 & $\mathrm{CM} 10 \mathrm{pH} 4.0$ & 11397 & 0.0079 & 0.833 & CM10 pH 4.0 \\
\hline 4544 & 0.0002 & 0.944 & CM10 pH 4.0 & 13909 & 0.0111 & 0.833 & IMAC30 \\
\hline 4582 & 0.0243 & 0.778 & CM10 pH 4.0 & 28094 & 0.0433 & 0.750 & IMAC30 \\
\hline 4761 & 0.0010 & 0.917 & CM10 pH 4.0 & 38025 & 0.0111 & 0.778 & IMAC30 \\
\hline 4763 & 0.0282 & 0.778 & CM10 pH 7.0 & & & & \\
\hline 4781 & 0.0022 & 0.889 & CM10 pH 4.0 & & & & \\
\hline 4828 & 0.0153 & 0.778 & Q10 pH 8.0 & \multirow{17}{*}{\multicolumn{4}{|c|}{$\begin{array}{l}\text { operating characteristic curve (ROC) of } \mathrm{m} / \mathrm{z} 4761 \text { is shown in } \\
\text { Fig. } 3 \mathrm{~b} \text {. The area under the curve (AUC) on the ROC was } \\
0.917 \text {. } \\
\text { In PC samples, single-marker analysis detected } 49 \text { mass } \\
\text { peaks that were significantly up-regulated and } 23 \text { peaks that } \\
\text { were significantly down-regulated, compared with peaks } \\
\text { obtained from benign lesion samples. Statistical data and } \\
\text { chip conditions of these peaks are shown in Table III. } \\
\text { To confirm reproducibility, we repeated the assay four } \\
\text { times in total using by CM10 chip with pH } 4.0 \text { binding buffer } \\
\text { Random selection from PMUS bank for repeated single- } \\
\text { marker analysis caused some overlaps of samples. So, finally } \\
\text { we analyzed } 37 \text { PC samples and } 39 \text { benign lesion samples } \\
\text { Results with repeated single-marker analysis are summarized } \\
\text { in Table IV. Although the significantly increased or decreased } \\
\text { peaks varied in each assay round, peaks of } \mathrm{m} / \mathrm{z} 10788 \text { showed } \\
\text { significantly lower intensity in the PC group throughout all } \\
\text { assay rounds. The peak of } \mathrm{m} / \mathrm{z} 5384 \text {, which showed } \\
\text { significantly lower intensity in } 3 \text { assay rounds, is deduced to } \\
\text { be a double charge of the peak of } \mathrm{m} / \mathrm{z} 10788 \text {. }\end{array}$}} \\
\hline 4862 & 0.0209 & 0.778 & Q10 pH 8.0 & & & & \\
\hline 4968 & 0.0001 & 0.944 & CM10 pH 4.0 & & & & \\
\hline 5017 & 0.0047 & 0.833 & Q10 pH 8.0 & & & & \\
\hline 5817 & 0.0209 & 0.778 & CM10 pH 4.0 & & & & \\
\hline 6200 & 0.0377 & 0.750 & Q10 pH 8.0 & & & & \\
\hline 6481 & 0.0027 & 0.833 & $\mathrm{CM} 10 \mathrm{pH} 4.0$ & & & & \\
\hline 8030 & 0.0039 & 0.833 & IMAC30 & & & & \\
\hline 8037 & 0.0007 & 0.889 & CM10 pH 4.0 & & & & \\
\hline 8202 & 0.0179 & 0.778 & CM10 pH 4.0 & & & & \\
\hline 8309 & 0.0179 & 0.806 & CM10 pH 4.0 & & & & \\
\hline 8871 & 0.0056 & 0.806 & CM10 pH 4.0 & & & & \\
\hline 9098 & 0.0056 & 0.806 & CM10 pH 4.0 & & & & \\
\hline 9102 & 0.0327 & 0.722 & IMAC30 & & & & \\
\hline 9207 & 0.0433 & 0.750 & CM10 pH 4.0 & & & & \\
\hline 9281 & 0.0047 & 0.833 & CM10 pH 4.0 & & & & \\
\hline 9780 & 0.0111 & 0.833 & CM10 pH4.0 & & & & \\
\hline
\end{tabular}

Table III. Continued. 
Table IV. Significant peaks detected by repeated single-marker analysis using by CM10 with pH 4.0 binding buffer.

\begin{tabular}{|c|c|c|c|c|c|c|c|c|}
\hline & \multicolumn{2}{|c|}{$1 \mathrm{st}$} & \multicolumn{2}{|c|}{$\begin{array}{l}\text { Assay round } \\
2 \text { nd }\end{array}$} & \multicolumn{2}{|c|}{$3 \mathrm{rd}$} & \multicolumn{2}{|c|}{ 4th } \\
\hline & $\mathrm{P}$-value & AUC & P-value & AUC & $\mathrm{P}$-value & AUC & P-value & AUC \\
\hline \multicolumn{9}{|c|}{$\begin{array}{l}\text { Up-regulated } \\
(\mathrm{m} / \mathrm{z})\end{array}$} \\
\hline 4761 & 0.0012 & 0.917 & 0.0112 & 0.861 & NS & - & NS & - \\
\hline 5817 & 0.0209 & 0.778 & 0.0413 & 0.742 & NS & - & 0.0338 & 0.643 \\
\hline 8037 & 0.0007 & 0.889 & NS & - & NS & - & 0.0351 & 0.609 \\
\hline 8871 & 0.0056 & 0.806 & NS & - & NS & - & 0.017 & 0.679 \\
\hline 9098 & 0.0218 & 0.806 & NS & - & NS & - & 0.0218 & 0.648 \\
\hline 9780 & 0.0111 & 0.833 & NS & - & NS & - & NS & - \\
\hline \multicolumn{9}{|c|}{$\begin{array}{l}\text { Down-regulated } \\
(\mathrm{m} / \mathrm{z})\end{array}$} \\
\hline 5384 & 0.0039 & 0.833 & NS & - & 0.0157 & 0.844 & 0.0393 & 0.617 \\
\hline 10788 & 0.0067 & 0.806 & 0.0162 & 0.783 & 0.0274 & 0.797 & 0.0474 & 0.644 \\
\hline
\end{tabular}

NS, not significant and AUC, area under the curve.

To create a heat map 72 significant peaks which identified in the first round single-marker analysis were used. According to the heat map based on the data from these 72 significant peaks (Fig. 4), we were able to discriminate PC from benign lesions with a sensitivity of $91.7 \%$ and a specificity of $83.3 \%$.

\section{Discussion}

SELDI-TOF and matrix-assisted laser desorption/ ionization-TOF MS have been recognized as the most common techniques for protein profiling (17). These techniques have been applied to discover a novel biomarker for PC $(11-13,18)$. However, recent studies emphasize on the limited usefulness of proteomic approach for identifying candidates for serum proteins (19). To overcome these problems, we conducted a proteomic study using PMUS. Most proteins synthesized in prostatic epithelium are secreted into prostatic acini and drained into the prostatic duct. Thus, PMUS is expected to be rich in proteins originating from prostatic epithelium. As demonstrated in the present study, protein concentration in PMUS was much higher than in urine. Moreover, this finding suggests that an abundant source of proteins in PMUS originates from the prostatic acini.

Lack of reproducibility in SELDI-TOF MS whole-serum proteomic profiling has also been noted (20). To overcome the weak point in reproducibility, we repeated our assays. For single-marker analysis we performed 4 rounds of SELDI-TOF MS analysis.

In the first single-marker analysis, we found 49 peaks that were significantly up-regulated in the patients with PC and 23 peaks that were significantly down-regulated. During the
4 rounds of assays, significant peaks varied from round to round. Among the significant peaks, a peak of m/z 10788 remained significant throughout all the rounds. Furthermore, the peak of $\mathrm{m} / \mathrm{z} 5384$, which showed significantly lower intensity in 3 assay rounds, may be a double charge of the peak of $\mathrm{m} / \mathrm{z} 10788$. Therefore, we believe that the peak of $\mathrm{m} / \mathrm{z}$ 10788 could be a promising single-marker for early detection of PC. Further study is required focusing on the structural analysis for this peak.

For HCA analysis, we used 72 peaks that proved significant in the first-round assay. In spite of the small sample size, we were able to discriminate biopsy-proven PC from benign lesions with high sensitivity and specificity by using the heat map. Especially, its high specificity of $83.3 \%$ is remarkably higher than that of PSA test for the detection of PC $(6,7)$. However, this method along with single-marker analysis, requires further investigation with a large number of samples.

In this preliminary study, we postulated that promising urine markers, originating from prostatic acini, can be obtained by prostatic massage. Our assays identified a potential marker to differentiate patients with PC from cancer-free subjects. However, as stated previously (21), all candidate markers must be strictly evaluated through multi-step checkpoints including accurate methods for detecting markers, single institutional pilot studies and rigorous validation in retrospective and prospective studies.

\section{Acknowledgements}

This study was supported by a grant from the CREST (Core Research for Evolutional Science and Technology) project of the Japan Science and Technology Agency. 


\section{References}

1. Stephenson RA: Prostate cancer trends in the era of prostatespecific antigen. An update of incidence, mortality, and clinical factors from the SEER database. Urol Clin North Am 29: 173-181, 2002.

2. Marugame T and Mizuno S: Comparison of prostate cancer mortality in five countries: France, Italy, Japan, UK and USA from the WHO mortality database (1960-2000). Jpn J Clin Oncol 35: 690-691, 2005

3. Lilja H, Christensson A, Dahlen U, Matikainen MT, Nilsson O, Pettersson K and Lovgren T: Prostate-specific antigen in serum occurs predominantly in complex with $\alpha 1$-antichymotrypsin. Clin Chem 37: 1618-1625,1991.

4. Stenman UH, Leinonen J, Alfthan H, Rannikko S, Tuhkanen K and Alfthan O: A complex between prostate-specific antigen and $\alpha 1$-antichymotrypsin is the major form of prostate-specific antigen in serum of patients with prostatic cancer: assay of the complex improves clinical sensitivity for cancer. Cancer Res 51: 222-226, 1991

5. Catalona WJ, Partin AW, Slawin KM, et al: Use of the percentage of free prostate-specific antigen to enhance differentiation of prostate cancer from benign prostatic disease: a prospective multicenter clinical trial. JAMA 279: 1542-1547, 1998.

6. Gretzer MB and Partin AW: PSA markers in prostate cancer detection. Urol Clin North Am 30: 677-686, 2003.

7. Catalona WJ, Smith DS and Ornstein DK: Prostate cancer detection in men with serum PSA concentrations of 2.6 to $4.0 \mathrm{ng} /$ $\mathrm{mL}$ and benign prostate examination. Enhancement of specificity with free PSA measurements. JAMA 277:1452-1455, 1997.

8. Ornstein DK and Petricoin EF: Proteomics to diagnose human tumors and provide prognostic information. Oncology 18: 521-519, 2004

9. Bons JAP, Wodzig WKWH and van Dieijen-Visser MP: Protein profiling as a diagnostic tool in clinical chemistry: a review. Clin Chem Lab Med 43: 1281-1290, 2005.

10. Adam BL, Qu Y, Davis JW, et al: Serum protein fingerprinting coupled with a pattern-matching algorithm distinguishes prostate cancer from benign prostate hyperplasia and healthy men. Cancer Res 62: 3609-3614, 2002.
11. Qu Y, Adam BL, Yasui Y, et al: Boosted decision tree analysis of surface-enhanced laser desorption/ionization mass spectral serum profiles discriminates prostate cancer from noncancer patients. Clin Chem 148: 1835-1843, 2002.

12. Petricoin EF III, Ornstein DK, Paweletz CP, et al: Serum proteomic patterns for detection of prostate cancer. J Natl Cancer Inst 94: 1576-1578, 2002.

13. Ornstein DK, Rayford W, Fusaro VA, et al: Serum proteomic profiling can discriminate prostate cancer from benign prostates in men with total prostate specific antigen levels between 2.5 and $15 \mathrm{ng} / \mathrm{ml}$. J Urol 172: 1302-1305, 2004.

14. Nickel JC: The Pre and Post Massage Test (PPMT), a simple screen for prostatitis. Tech Urol 3: 38-43, 1997.

15. Greene FL, Page DL, Fleming ID, Fritz A, Balch CM, Haller DG and Morrow M: AJCC. In: Cancer Staging Manual (eds). 6th edition. Springer-Verlag, New York, pp317-312, 2002.

16. Epstein JI, Allsbrook WC Jr, Amin MB, Egevad LL and ISUP Grading Committee, The 2005 International Society of Urological Pathology (ISUP) Consensus Conference on Gleason Grading of Prostatic Carcinoma. Am J Surg Pathol 29: 1228-1242, 2005.

17. Wulfkuhle JD, Liotta LA and Petricoin EF: Proteomic applications for the early detection of cancer. Nat Rev Cancer 3: 267-275, 2003

18. Partin AW and Chan DW: Detection of prostate cancer using serum proteomics pattern in a histologically confirmed population. J Urol 171: 1782-1787, 2004.

19. McLerran D, Grizzle WE, Feng Z, et al: SELDI-TOF MS whole serum proteomic profiling with IMAC surface does not reliably detect prostate cancer. Clin Chem 54: 53-60, 2008.

20. Rogers MA, Clarke P, Noble J, Munro NP, Paul A, Selby PJ and Banks RE: Proteomic profiling of urinary proteins in renal cancer by surface enhanced laser desorption ionization and neural-network analysis: identification of key issues affecting potential clinical utility. Cancer Res 63: 6971-6983, 2003.

21. Parekh DJ, Ankerst DP, Troyer D, Srivastava S and Thompson IM: Biomarkers for prostate cancer detection. J Urol 178: 2252-2259, 2007. 